\title{
The Effect of High-Rise Building Features on Their State under the Horizontal Seismic Loads
}

\author{
Igor Korobiichuk \\ Warsaw University of Technology, Institute of Automatic Control and Robotics, Warsaw, Poland
}

Michał Nowicki, Katarzyna Rzeplińska-Rykała

Industrial Research Institute for Automation and Measurements PIAP, Warsaw, Poland

\section{Andrii Shostachuk, Dmytro Shostachuk, Artem Sazonov \\ Zhytomyr State Technological University, Zhytomyr, Ukraine}

\begin{abstract}
The action of high-rise building state under the horizontal seismic loads is considered. The action of elastic features of the high-rise buildings supporting structures on their stressed state change with the horizontal seismic loads is defined and the appropriate correction factor is presented.
\end{abstract}

Keywords: high-rise building, horizontal seismic loads, stressed state, Earth seismic motion

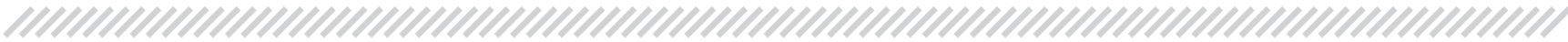

\section{Introduction}

Construction of skyscrapers and other high-rise buildings is the characteristic feature of the modern cities because in the deficit of construction areas it makes it possible to concentrate apartments, banks, markets, exhibitions etc. on small areas and in the single buildings. The features of a high-rise building (height, mass, high ground pressures and pressures on bottom, oscillations, difficulty of evacuation in case of emergency) define risks for people staying in the high-rise building and next to it $[1-5]$. These factors impose a lot of requirements to use of the buildings, like the uninterrupted work of its installations, building's stability under the wind or seismic load, terroristic attack, etc.

Vulnerability to earthquakes is one of the features of the high-rise building's functioning features, especially to their horizontal component [6,7]. Vulnerability of the high-rise buildings increases along with their height [8-10], and also when the building mass is reduced because of employment of new materials, and rational use of their load bearing capacity. The building's mass decrease results in their flexibility increase, and stiffness and frequency oscillations decrease. The increase of the building stiffness makes its wind resistance higher but also increases the vulnerability of structures to a seismic impact. Building stiffness changes can be achieved by modifications of the building's cross-section moment of

Autor korespondujący:

Igor Korobiichuk, kiv_Igor@list.ru

Artykuł recenzowany

nadesłany 29.04.2016 r., przyjęty do druku 31.05.2016 r. inertia. However, obviously, the main parameter which will define both the resistance to wind and seismic loads is the height of the building, but it defines its internal volume (area), future architectural face, validity of its location among other smaller buildings, prestigiousness, and justification of its parts. The height rise leads to increasing sensitivity to buckling under wind loads. Regarding seismic loads, height increase, from our point of view, make ambiguous effect on high-rise buildings stability, because height increase when lateral dimension is constant leads to building mass increase and height of its centre of gravity. This leads to increase of the shear force under seismic loads. On other hand, tall buildings are more flexible and resist the accelerated motion of bottom better. Therefore, it is important to evaluate the effect of building height to its resistance to seismic loads. The goal is to formulate the character of building height influence on the stressed state, changing with the horizontal seismic loads.

\section{Ivestigation of High-Rise Building State under the Horizontal Seismic Loads}

As of today, a lot of publications which are devoted to the external action on the high-rise buildings concern wind loads $[11,12]$. It is explained by the continuity of wind flow along a side of the high-rise building. However, there is not enough research concerning the high-rise buildings affected by the seismic shocks. There are a lot of regions with no seismic activity for years or decades. At the same time, is it necessary to build the high-rise buildings in regions with the seismic activity. And besides, damages of the supporting structures caused by earthquake may be like damages caused by fire or terroristic act. Another difficulty with the simulation of the high-rise building's behaviour during an earthquake is its unpredictability and also unpredictability of duration, force, direction, etc. At the same time, wind direction and force value are known for this area from meteorological observations. 
In $[13,14]$ the systems of high-rise buildings protection from seismic impact are considered. Seismic isolation system and system of seismic dumping are discussed. It is shown that seismic isolation which can be bottom mounted and other height for mount are a safer protection than the seismostable buildings, because it provides less damages of the main structure of building (columns, walls, frames). The complex seismic isolation system and system of seismic dumping will make it possible to use buildings even after the earthquake, providing the simultaneous checking and repair of the structures' components. Only a few research works related to the high-rise building stiffness [15-19] are known and should be mentioned. The analysis of systems of the passive and active earthquake protections are presented in the first one and also requirements for the systems of high-rise buildings earthquakes passive compensation, the one's own original system of the kinematic earthquake dumper is proposed either. The latter contains rolling friction and dumpers with determined stiffness and damping factors. In [19] the analysis of basement compliance to reinforced concrete structures under seismic impact is given and also model of a sliding zone with a nonlinear damping either of which isolates the high-rise building in case of earthquake.

In this research, a trial there was done to evaluate the difference between deformation or stiffness state, which theoretically arises in the absolutely rigid building and deformations which really occur in high-rise building. The difference is conditioned by elastic features of the supporting structures. Let us consider the high-rise building behaviour during the horizontal earth shocks impact. Let's assume that center of mass of the high-rise building is in the middle of the distance between earth's surface and the top of the high-rise building. The non-emerging elastic features of the supporting structures when center of mass of the high-rise building moves synchronously to earth's surface the top of high-rise building deviation defines [20] are:

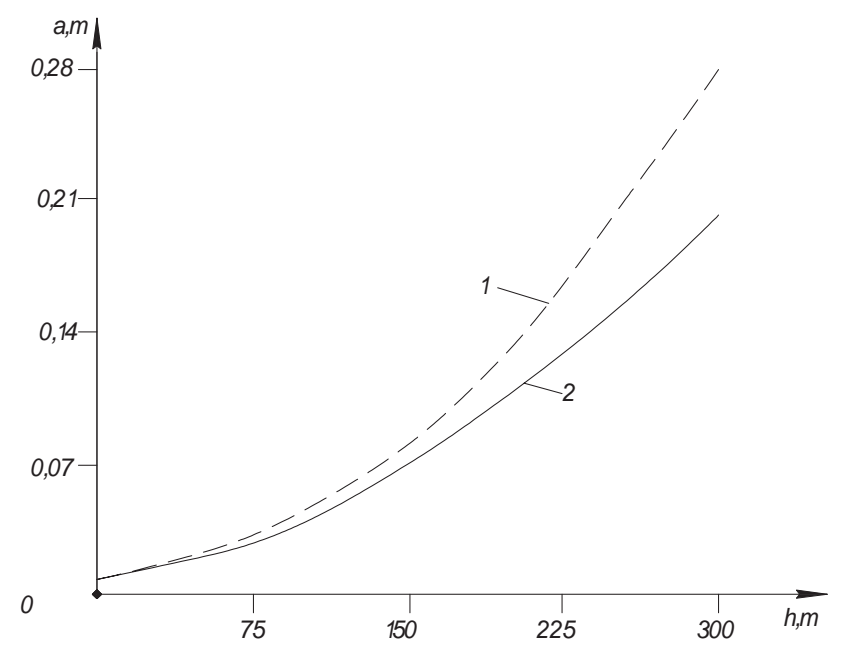

Fig. 1. Deviation of the top of high-rise building $(a, m)$ versus its height $(h, m)$

Rys. 1. Zależność wychyłu szczytu wysokościowca $(a, m)$ od jego wysokości $(h, m)$

$$
\delta_{1}=\frac{1}{6 E \cdot I} \cdot \mathrm{F}_{\tilde{n}} \cdot b_{\tilde{n}}^{3} \cdot\left(2+3 \frac{a_{\tilde{n}}}{b_{\tilde{n}}}\right) \leq[\delta],
$$

where:

$E$ - elasticity modulus of the supporting structures material, $I$ - moment of inertia of cross-section of the high-rise building supporting structures,

$F_{c}$ - shear to axis of high-rise building load determined seismic impact,

$b_{c}, a_{c}$ - the distances of shear load place, determined earthquake, the earth's surface and the top of high-rise building respectively,

$[\delta]$ - maximum high-rise building vertical deviation, should be less then 0.001 of the building height.

Supporting structures compliance increase will lead to vertical deviation of the top of high-rise building rising and on other hand - to decrease shear of vertical axis of high-rise building load called by earth's surface accelerate motion. That is, because the high-rise building structure is a non-rigid body, and its supporting structures have a predetermined elasticity modulus (steel or concrete for example), the inertial relative to earth's surface center of mass motion of the high-rise building in opposite to bottom motion direction would occur with seismic shocks, besides acceleration of the building center of mass motion caused by the Earth seismic motion are smaller than calculated according to equation (1). The tension in supporting structures with essential value of compliance will determine not only earth's surface acceleration, but also the value of deviation of high-rise building top from its axis. The deviation will call forth bending moment which leads to high-rise building damped oscillations.

Figure 1 shows the results of calculations made using equation (1) for the next data: acceleration of Earth's surface shake is $0.9 \mathrm{~m} / \mathrm{s}^{2}$, corresponded to moderately dangerous oscillation $(0.8-1.8) \mathrm{m} / \mathrm{s}^{2}$, 7 balls, duration of the shake is 4 sec, elasticity modulus of the supporting structures material for height of $75 \mathrm{~m}$ is $E=0.2 \cdot 10^{11} \mathrm{~Pa}$. The rising height leads to increase of the vertical deviation (Figure 1, curve 1). The essential value of this deviation can be dangerous, therefore the deviation value can be controlled by the changing value of moment of inertia. The last change of both the rising cross-section area of the vertical bearing and changing scheme of the high-rise building includes additional links between vertical bearings (the second way is more attractive from the standpoint of the decreasing building mass and material saving). The second curve (Figure 1) shows the decrease of the deviation of the top of high-rise building owing to moment of inertia changing. At the height of $75 \mathrm{~m}$ the moment of inertia increase grows to $6 \%$, at the $300 \mathrm{~m}-43 \%$.

It is obvious that improvement of compliance will lead to decreasing of the cross-section of the building axis force also to less damages of supporting structures. The dangerous consequences of the cross-section impact increase due to height rising, in this regard it is desirable to increase the compliance of high-rise building supporting structures. 
Figure 2 shows plot of the cross-section force caused by accelerated motion of the earth's surface depending on increase of the supporting structures compliance. Here $k=F / F_{0}$, where $F$ and $F_{0}$ are the cross-section forces with different compliance of supporting structures of high-rise building. It seems the building height rising decreases the value of cross-section force.

It is obvious, that except the possible earthquake it is necessary to take into consideration the wind load and search the reasonable compromise between stiffness and compliance of the supporting structures.

Thus, such factors can be related to the operating characteristics of high-rise buildings, as: the complexity of high-rise buildings, mechanical design; large mass, and correspondingly high pressure on the soil and foundation; a constant pressure of wind, of variable speed and direction; a significant number of factors that can interfere with the normal operation of tall buildings (earthquakes, subsidence in the loess soils, floods, violation of the strength and stability of the structure, abnormally high or low temperatures, fire); a significant number of people who are at the same time in areas of tall buildings and the complexity of their evacuation; a significant amount of engineering required to sustain life in areas of tall buildings (water supply, heating, air conditioning, vertical transportation, vibration, etc.).

Considering the above, it can be stated that the indicators of the functioning of high-rise buildings are a fairly large group of parameters, control of which is only possible by appropriate automated systems, which are combined into one comprehensive global monitoring system. Among these automated systems, there can be: video monitoring; emergency lighting; automated fire alarm and fire extinguishing; monitoring the condition of the structure and foundations of buildings; monitoring the status of civil engineering objects; evacuation management.

The effective functioning of such a global system can be carried out only with the use of feedback, in which the parameters are coming to the comparison blocks, and further to a central control point.

The number of such systems for every high building has an individual character. Such a system should include the primary central module, which will be the main center for the general hierarchy, and a set of grouped systems (according to the function similarity), which also have a collection of lower level subsystems.

A large number of life support systems and the need for their proper interaction in order to create the conditions crucial to make the right decisions in the management of the object, forces the use of a system to approach the management of complex objects such as tall buildings.

The control system consists of the following components:

- Automatic control system,

- Computer control system.

The automatic control system executes automatic correction algorithms of parameters that are controlled.

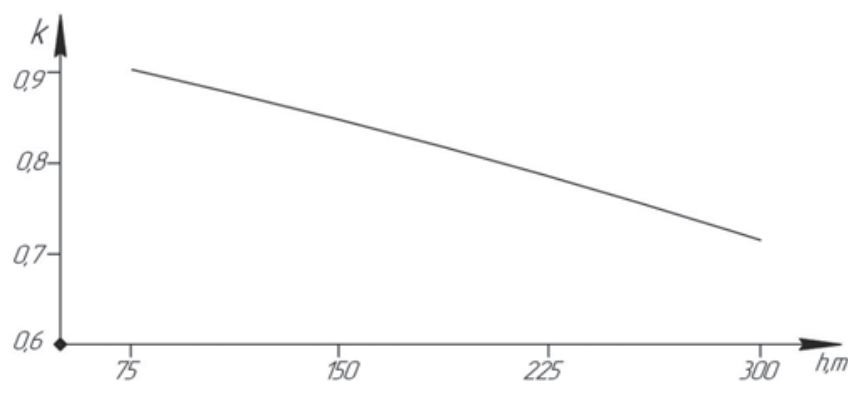

Fig. 2. Correction factor $k$ for reduction of cross-section force decrease in supporting structures of the high-rise building depends on height $h, m$

Rys. 2. Współczynnik korekcyjny k zmniejszający siły w przekroju poprzecznym elementów nośnych wysokościowca zależy od wysokości $h, m$

Therefore, we can underline the tasks of the control system for management of complex system, such as the high-rise building:

- Formal description,

- Structural and functional analysis of a complex system,

- System management of the complex object,

- Information analysis of system's tasks,

- Decision-making process based on the data.

\section{Conclusions}

The high-rise building behavior with horizontal seismic loads is considered and also determined that dangerous state of high-rise building needs to be ascertained by the maximum deviation of the top or by the value of shear loads in cross-section of supporting bearings, dependent on seismic loads value.

The mechanism of compliance features impact of supporting bearings of the high-rise building on decreasing the negative influence seismic loads is determined, and the appropriate comparative graphics are also obtained.

The correction factor which adjusts the decrease of the value of cross-section force in the supporting structures with the impact of horizontal seismic deformations during increasing of the compliance of high-rise buildings supporting structures is proposed.

\section{References}

1. Shostachuk A.M., Emergence of environmental hazards upon construction of high-rise buildings in urban conditions. Proceedings of the $6^{\text {th }}$ International Scientific Conference "Practical aerospace and high technology", dedicated to the $100^{\text {th }}$ anniversary of the birth of Academician S.P. Koroliov, Zhytomyr, January 9-11, 2007, 92-93.

2. Safak E., Kaya Y., Skolnik D., Ciudad-Real M., Al Mulla H., Megahed A., Recorded response of a tall buildings in Abu Dhabi from a distant large earthquake. NCEE $2014-10^{\text {th }}$ U.S. National Conference on Earthquake Engineering: Frontiers of Earthquake Engineering. 2014.

3. Chen Q.-J., Yuan W.-Z., Li Y.-C., Cao L.-Y., Dynamic response characteristics of super highrise buildings subjected to long-period ground motions. "Journal of Central South University", 
Vol. 20, Issue 5, 2013, 1341-1353, DOI: 10.1007/ s11771-013-1621-9.

4. Korobiichuk I., Shostachuk A., Shostachuk D., Shadura V., Nowicki M., Szewczyk R., Development of the Operation Algorithm for a Automated System Assessing the High-rise Building. "Solid State Phenomena", Vol. 251, 230-236. DOI:10.4028/www.scientific.net/ SSP.251.230.

5. Tang Y., Zhao X., Field testing and analysis during top-down construction of super-tall buildings in Shanghai. "KSCE Journal of Civil Engineering", Vol. 20, Issue 2, 2016, 647-661, DOI: $10.1007 / \mathrm{s} 12205-015-1529-\mathrm{z}$.

6. Nikolaev S.V., Safety and reliability of highrise buildings is a set of high-profile solutions. "Construction security" [Безопасность и надёжность высотных зданий - это комплекс высокопрофильных решений. Строительная безопасность], 2005, http://www.securpress.ru/issue/sb/2005/visot_ safety.htm.

7. Li J., Xie X., Zhang Q., Fang P., Wang W., Distress evaluation and remediation for a highrise building with pile-raft foundation, "Journal of Performance of Constructed Facilities", Vol. 28, Issue 4, 2014, DOI: 10.1061/(ASCE) CF.1943-5509.0000503.

8. Kozak J., High-rise building structures [Конструкции высотных зданий], М.: Stroiizdat, 1986, 308 p.

9. Dorvash S., Pakzad S., Naito C., Hodgson I., Yen B., Application of state-of-the-art in measurement and data analysis techniques for vibration evaluation of a tall building. "Structure and Infrastructure Engineering", Vol. 10, Issue 5, 2014, 654-669, DOI: 10.1080/15732479.2012.757795.

10. Poulos H.G., Challenges in the design of tall building foundations. Geotechnical Engineering. Vol. 45, Issue 4, 2014, 108-113.

11. Popov N., Wind impact on high-rise buildings [Воздействия ветра на высотные здания]. "Tall Buildings", No. 3, 2007, 66-69.

12. Stoyanoff S., Xie J., Wind loads: problems and solutions [Ветровые загрузки: проблемы и решения]. "Tall Buildings", Vol. 2, 2007, 82-85.
13. Systems for improvement of structure seismic stability (materials of Nikken Sekkei) [Системы поышения сейсмостойкости сооружений (материалы компании Nikken Sekkei)]. Tall Buildings, No. 1, 2010, 100-103.

14. Wang G., Zhang S., Zhou C., Iu W., Correlation between strong motion durations and damage measures of concrete gravity dams, "Soil Dynamics and Earthquake Engineering", Vol. 69, 2015, 148-162, DOI: 10.1016/j. soildyn.2014.11.001.

15. Chipko S.A., Burtseva O.A., Compensation system for the high-rise structure fluctuations in an active seismic area [Система компенсации колебаний высотного сооружения в сейсмоактивной зоне]. http://www.ivdon.ru/ uploads/article/pdf/IVD_45_Chipko.pdf_2249. pdf.

16. Volkov D., Zheltukhin S., Preferred frequencies for coupling of seismic waves and vibrating tall buildings. "Soil Dynamics and Earthquake Engineering", Vol. 74, 2015, 25-39, DOI: 10.1016/j.soildyn.2015.03.004

17. Valla M., Gueguen P., Augère B., Goular D., Perrault M., Remote modal study of reinforced concrete buildings using a multipath lidar vibrometer. "Journal of Structural Engineering" (United States). Vol. 141, Issue 1, 2015, DOI: 10.1061/ (ASCE)ST.1943-541X.0001087.

18. Kostinakis K., Athanatopoulou A., Morfidis K., Correlation between ground motion intensity measures and seismic damage of $3 D R / C$ buildings, "Engineering Structures", Vol. 82, 2015, 151-167, DOI: 10.1016/j.engstruct.2014.10.035.

19. Nguyen Quoc Dong, Dynamic calculation of highrise buildings upon earthquake [Динамический расчет многоэтажных зданий при землетрясении]. Abstract IA to for $\mathrm{PhD}$ in Engineering. Specialty 05.23.17, GOU VPO Saint Petersburg State Architectural and Construction University Science, St. Petersburg 2010.

20. Pisarenko G.S., Yakovlev A.P., Matveev V.V., Material resistance manual [Справочник по сопротивлению материалов]. Naukova Dumka, Kiev 1988.

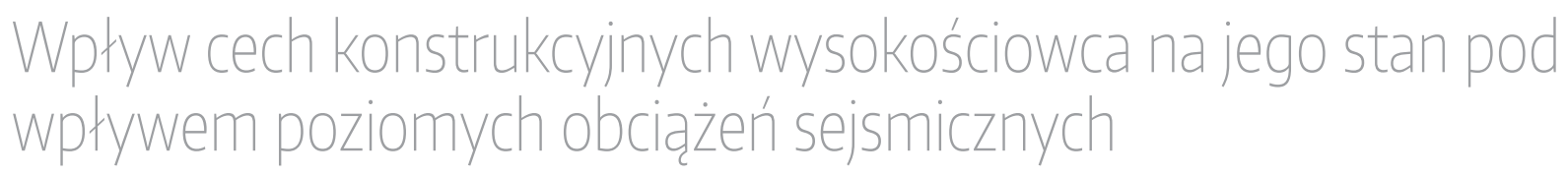

Streszczenie: W artykule opisano zachowanie wysokościowca pod wpływem poziomych obciążeń sejsmicznych. Opisano stan odkształceń sprężystych struktur nośnych w wysokich budynkach pod wpływem drgań sejsmicznych, oraz przedstawiono odpowiedni współczynnik korekcyjny. 
Igor Korobiichuk

kiv_lgor@list.ru

He received PhD degree in Instrument and Methods for Measuring Mechanical Quantities from National Technical University "Kyiv Polytechnic Institute", Kyiv, Ukraine in 2008. Now he works at the Institute of Automatic Control and Robotics. His current research interests include measuring systems, automation of control systems, mathematical model and aviation gravimetric system.

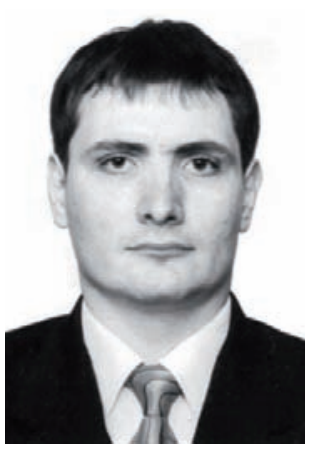

Michał Nowicki, MSc

mnowicki@mchtr.pw.edu.pl

Now he works as engineer at Industrial Research Institute for Automation and Measurements PIAP. His current research interests include magnetic materials research, measuring systems, aviation gravimetric system and industrial measurements.

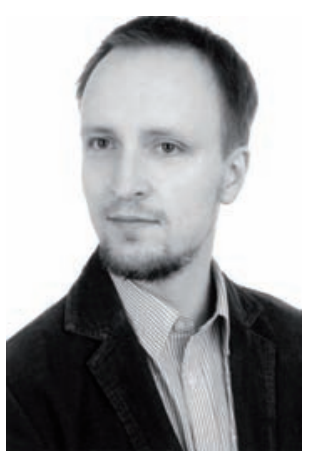

Andrii Shostachuk, PhD andreich97@mail.ru

He received PhD degree in Mechanics of Deformable Solids from Ivan Poului Ternopil State Technical University of Ukraine, Ternopil, Ukraine in 2003. Now he works at Zhytomyr State Technological University. His current research interests include urban ecology, safety of high-rise building usage, engineering ecology.

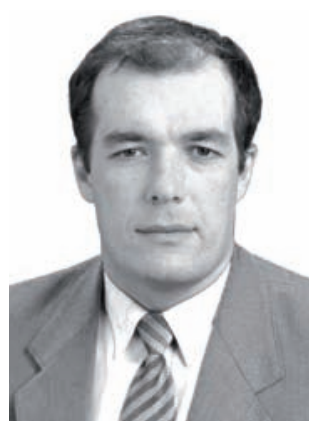

\section{Dmytro Shostachuk, PhD}

d.shostachuk@gmail.com

He received PhD degree in Gyroscopes and Navigation System from National Technical University of Ukraine „Kyiv Polytechnic Institute", Kyiv, Ukraine in 2003. Now he works at Zhytomyr State Technological University. His current research interests include optimization methods, system analysis of the complex control objects, mathematical modeling.

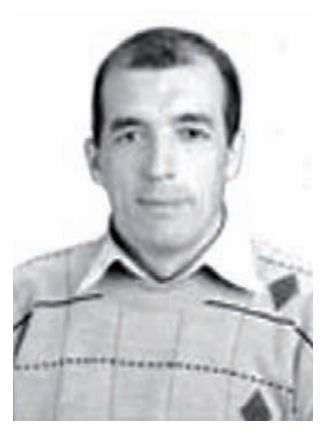

Artem Sazonov, PhD

artyomsazonov@mail.com

He received PhD degree in Automation of Processes Control from National Technical University of Ukraine „Kyiv Polytechnic Institute", Kyiv, Ukraine in 2014. Now he works at Zhytomyr State Technological University. His current research interests include mechatronic systems, accuracy of industrial robots, CAD/CAM/CAE Technologies, synthesis and design of the Flexible integrated systems.

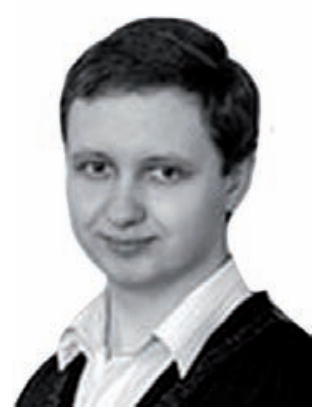

